\title{
Ozone Sterilization
}

National Cancer Institute

\section{Source}

National Cancer Institute. Ozone Sterilization. NCI Thesaurus. Code C101690.

A sterilization process that uses ozone gas to kill microorg anisms. This process may be used on objects that cannot withstand high temperatures. 